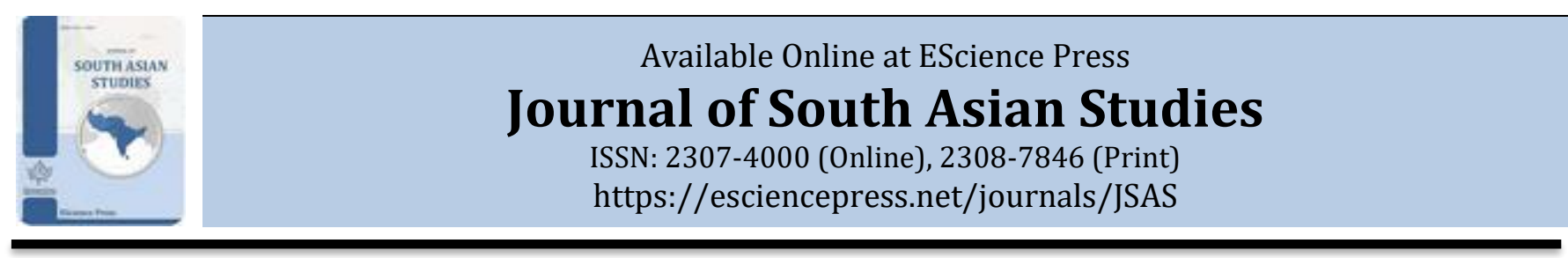

\title{
ECONOMIC DEVELOPMENT AND FEMALE LABOR FORCE PARTICIPATION IN BANGLADESH: A TEST OF THE U-SHAPED HYPOTHESIS
}

\author{
Soma Dhar* \\ Department of Economics, University of Chittagong, Chittagong, Bangladesh.
}

*Corresponding Author Email ID: soma.chowdhury7@yahoo.com

\section{A B S T R A C T}

The study aims to explain the relationship between economic development measured by GDP per capita on PPP and female labor force participation rate (FLFPR) in Bangladesh. Using Time series data from (1991-2019), extracted from secondary data sources; the study develops three models to test the U-shape hypothesis. The study uses control variables such as Female Unemployment rate, Fertility rate, and Urbanization. The Ordinary Least Square Regression Analysis is used to run the regression by using Econometric Software STATA (version12.0). The regression result indicates that the Female unemployment rate has a positive impact on FLFPR. Fertility rate and Urbanization have a negative effect. There is a significant impact of the quadratic GDP per capita PPP on FLFPR. The overall results of this paper suggest that a U-shape does not exist in Bangladesh. The research investigates an upward pattern in the female labor force participation rate by measuring the relationship between economic growth and female labor force participation rate in Bangladesh.

Keywords: Economic Development, Economic Sectors, Female Labor Force Participation Rate, OLS Regression, UShaped Hypothesis.

\section{INTRODUCTION}

The U-shaped hypothesis is a stylized explanation of the relationship between the female labor force participation rate and economic development regarding GDP per capita. The strategy posits that female participation rates are highest in developing countries, where women are engaged in subsistence farming and fall in middle-income countries because of shifts of men to industrial works. With the improvement of education levels and fertility rates, mortality rates fall, women can engage themselves in the labor force in response to growing demand in the services sector. This transition is somehow a stylized fact, but it is not robust to different data sets and econometric methodologies. Albeit some countries follow this hypothesis, many labor markets do not reveal this Ushaped relationship (Verick, 2018).

The U-shaped hypothesis suggests a range of trade-offs between macroeconomic gain regarding economic growth and female labor force participation for the developing countries. This transaction is pivotal for policymakers to advocate concrete macroeconomic policies. The policy is to identify trends in labor force participation and to draw an outline and execute. Female participation in the workforce has a vital role to play in the development process of a country.

An upward trend for female labor force participation rate in Bangladesh may safeguard the growth of the country. It is relevant to the correlation between female labor force participation rates (FLFPR) and its determinants. FLFPR follows a nonlinear ' $U$ ' shaped pattern as a country develops. A couple of studies have tried to sketch this ' $U$ ' shaped picture of the female labor force participation rate as a country evolves.

Sinha (1967) notes in the 'feminization ' $U$ ' hypothesis' that the impact of growth on female labor force participation rate is assumed to be curved. i.e., FLFP initially declines with widen and then rises in the long run. Goldin (1995) notes that U-shape hypothesis is a relationship between women's educational attainment and advances in economic development. At a more 
immature stage of economic growth, the income effect commands the substitution effect. But with more inclusive access to female higher education makes the substitution effect powerful than the Income effect, and the labor supply function bends upward. This U-shape is only applicable for developed countries with crosssection data.

Following the previous studies, the study runs the OLS regression analysis with three models. Model 1 shows the regression with Female labor force participation on the Natural log of GDP per capita PPP (Constant 2011 US dollar) and its quadratic value. Then I showed the diagram of the female labor force participation rate in Bangladesh from (1991-2019). Last, we get the actual shape which employs the relationship between economic development and female labor force participation rate. Model 2 examines the control variables that affect female labor force participation. In Model 3, the study uses the value-added of the three economic sectors (Agriculture, Industry, and Service) as explanatory variables with GDP per capita PPP.

However, the major shortcoming of this study is that literacy rate is not included in the model as a control variable due to unavailable data, even if literacy rate is the most valuable determinant of female labor force participation rate. Since the development of female education suggests that transforming education into a tool for women's empowerment requires a fundamental change in the perception of women as equal actors for gender-equal economic growth. Education can play an instrument of the power of women. Educational achievements for women can increase the natural outcome of the growth process.

In this study, I tried to show the correlation between female labor force participation rate and the female literacy rate for the selective years from UNICEF Data. Section 2 illustrates the impact of some crucial factors on the female labor force participation rate. Section 3 investigates the status of Bangladesh in the Female labor force participation rate among other South Asian countries and verifies the U-shape in all South Asian countries. The Literature Review is in Section 4. Empirical findings based on Correlation and Multiple Regression Estimates are in Section 5. Section 6 employs the
Concluding Remarks.

\section{SOME CRUCIAL FACTORS THAT CAN AFFECT FEMALE LABOR FORCE PARTICIPATION RATE}

Verma (1990) noted that four factors circumscribe female labor force participation four determinants which are as follows:

- Perpetual and insufficiency of the income of the principal breadwinner.

- Transient reduction in the family's income due to unexpected situations.

- The destruction of the breadwinner; and

- Women's grade for economic independence or an adjusted higher standard of living for the family.

These four factors are paramount but, Verma (1990) claimed that it is tough to designate the low female labor participation rate to any distinguishing factor. Notwithstanding, we count four factors additionally as explanatory variables. These are as follows:

Buffer Factor: The buffering hypothesis supposes that women as an agile reserve army of labor, during accelerations female labor force assistance increases, and during downturns, the rate starts to decline.

Segregation Factor: As per the job segregation hypothesis, demand for female labor is pertinent to enjoin the predominant sectors. That means the proposition protects women from being last-hired and first-fired.

Substitution Factor: According to the substitution hypothesis, women become substituted for men workers during the collapse as a cost-saving stratagem.

Income Factor: According to the income hypothesis, women participate in the labor market to ensure their income insufficiency and strengthen their socioeconomic living standards.

\section{COMPARISON WITH OTHER SOUTH ASIAN COUNTRIES}

Women in South Asia remain to be continuing out of the region's economic prosperity. Globally, South Asia is the fastest-growing region. The female labor force participation rate is only 23.6 percent versus 80 percent for men (World Bank, 2020).

In South Asia, female participation rates fluctuate from under 30 percent in Pakistan, India, and Afghanistan to almost 80percent in Nepal and near 60 percent in Bhutan, shown in Table 1. 
Table 1. Labor Force Participation Rate, Female (\% of Female Population ages 15+).

\begin{tabular}{l|lllllll|l}
\hline Year & Bangladesh & India & Pakistan & Sri Lanka & Nepal & Maldives & Bhutan & Afghanistan \\
\hline 1990 & 24.65 & 30.27 & 13.95 & 45.51 & 81.38 & 20.21 & 61.44 & 15.32 \\
1995 & 25.63 & 30.61 & 12.51 & 36.33 & 81.67 & 28.17 & 59.93 & 15.38 \\
2000 & 26.82 & 30.41 & 16.07 & 37.29 & 81.41 & 37.43 & 61.98 & 14.85 \\
2005 & 27.8 & 31.79 & 18.38 & 36.86 & 80.13 & 37.39 & 65.22 & 15.78 \\
2010 & 29.85 & 25.85 & 21.72 & 34.41 & 79.43 & 39.8 & 63.52 & 15.13 \\
2015 & 32.37 & 21.79 & 23.86 & 35.74 & 80.37 & 45.05 & 58.27 & 18.76 \\
\hline 2019 & 36.37 & 20.79 & 21.67 & 33.55 & 81.52 & 41.61 & 59.46 & 21.76 \\
\hline
\end{tabular}

Source: ILOSTAT Database

Bangladesh is one of the few countries in South Asia that has encountered an accelerated increase in women's participation in work from agriculture to the service sector, which attribute to the growth in the Ready-Made Garment industry and microcredit program (Rahman et al., 2013). Notwithstanding a historically high level of human improvement and muscular economic growth in current years, female labor force participation rates in Sri Lanka have settled abundantly connected, equalizing around 33 percent (Gunatilaka, 2013). Female labor force participation rates in the Maldives are almost 42 percent in 2019, ranking 3rd in South Asian countries. (Chaudhary \& Verick, 2014) noted that the rate of female labor force participation was in South Asia (31.1 percent) in 2012, while the global average was 51.1 percent. In 2019, the ranking of Bangladesh was 154 out of 181 countries in the world.

To verify the U-shape hypothesis in South Asian countries by scatter plot diagram, we use GDP per capita PPP and FLFPR for all countries (see Appendix). In the scatter plot, we measure economic development as $\mathrm{X}$-axis value and Female labor force participation rate as Y-axis value for all South Asian countries. From the scatter plot, we can come to a decision that only Nepal and Bhutan have Ushape patterns. Bangladesh has only an upward trend shape, not U-shape. India has an upward shape, Pakistan and Maldives have an inverted U-shape, Sri Lanka has a steady pattern, and due to lack of data, we cannot take any judgment for Afghanistan.

To be specific, not all countries have resulted in such a Ushaped track as their economies have grown. For example, the female labor force participation rate rose from 25 percent in 1991 to 36 percent in 2019 in Bangladesh. Female labor force participation in Bangladesh commenced at much cheaper levels of industry than service level before proceeding over the 2000 s due to the blast in the garment industry and microcredit (Rahman et al., 2013). Thus, connecting the complex development of the relationship between economic growth and female labor force participation in developing countries genuinely to changes in per capita GDP on PPP obscures the reality of multiple teams at play.

\section{LITERATURE REVIEW}

Sundry researchers recommended a U-shaped, long-term relationship between female labor force participation rate and economic development. The long-term U-shaped relationship describes the feminization of the labor force and the level of economic growth (Sinha, 1967). Industrial augmentation marginalizes women demotivate their participation in pay work, which portrays the U-shaped female labor force participation (Bosherup, 1970).

(Pampel \& Tanaka,1986) opine that having a high GDPoriented country has the highest female labor force participation rate while having a low GDP-oriented country has the lowest female labor force participation rate. (Tansel, 2001) investigates Time series data on female labor force participation rates in Turkey and analyzes its cross-provincial determinants using data for 67 provinces for the time points-1980, 1985, and 1990 which established the behavior of the U-shape hypothesis. Tam (2011) analyzed a worldwide panel of 130 countries between 1950 and 1980 using the dynamic panel data estimation. The empirical results confirmed that the U-shaped relationship between feminization of the labor force and real GDP per capita was an intertemporal relationship. The U-shaped curve demonstrates shifts from a subsistence agriculture economy to an industrialized and labor-intensive economy which suggests the existence of a trade-off between economic growth and women`s equal access to the labor market in the early degrees of economic growth. The expanding female labor force in the labor market, indicated by the developing portion of the Upattern, is called the Re-feminization of the labor force develops (Gaddis \& Klasen, 2013). 
Chapman (2015) investigated the negative relationship between economic development and FLFPR using panel data for 20 countries in the Middle East and North Africa (MENA) between 1990 and 2012.

Husain (2016) shows a Quadratic U-shaped labor supply function for women of Bangladesh from (1991-2012). She points out the level of per capita GDP exceeding which the U Curve bends upward. Khaliq et al. (2017) suggest the presence of a long-run and a U-shaped link between economic growth and FLFPR in Pakistan using time series data between 1990 and 2014. Mehrotra et al. (2017) explore the socio-economic determinants of the female labor force in India. They examine the U-shape female labor force participation rate using micro and macrolevel indicators by investigating the income and substitution effect of the actual wage increase. They obtained a powerful negative income effect that surpasses the positive substitution effect, and as a result, FLFPR has declined substantially.

Roy (2018) presents a scatter diagram to display the correlation between FLFPR and GDP pc PPP of India from (1991- 2016). She suggests two distinct "U" patterns in India notice for two different periods, which are (19912005) for period one and (2005-2016) for period two. By using linear and quadratic models for both periods, we use separate OLS regression to estimate the regression.

(Altuzarra et al.,2019) investigate the relationship between female labor force participation rate and economic development in 28 countries of the European Union for the period of 1990-2016 by using three estimations of Static (Ordinary Least Square), Fixed Effects and Dynamic (GMM) models that suggest the existence of $U$-shape relationship.

(Altarawneh, 2020) examines the U-shape relationship between female labor force participation rate and economic development in Jordan by using the Dynamic Lease Squares (DOLS) approach. The experimental results verified a $U$-shaped relationship between the quadratic GDP per capita and the female participation rate. The overall result suggests that the Added Worker Effect (AWE) dominates over the Discouraged Worker Effect (DWE) as the GDP per capita showed a negative and significant impact on FLFPR.

Some researchers disagree with this U-shaped pattern for female labor force participation during economic development. Durand (1975: 150) concludes that, albeit initially female labor force participation in agriculture diminishes with economic growth, the U-shape hypothesis is not a general pattern of female participation rates in developing countries.

Lahoti and Swaminathan (2013) investigate the relationship between economic development and female labor supply using state-level data fording from 19831984 to 2011-2012 in India, using the Ordinary Least Squares (OLS) technique. The experimental conclusions did not recommend the U-shaped hypothesis, unveiled no meaningful relationship between economic growth and FLFPRs. According to Mahmud (2003), a U-shaped relationship between economic growth and female labor force participation rate in Bangladesh does not fit.

\section{EMPIRICAL FINDINGS BASED ON CORRELATION AND MULTIPLE REGRESSION ESTIMATES}

To verify the $U$ shape hypothesis, we try to figure out the trade-off between economic development and female labor force participation rate in Bangladesh. So many macro-level factors affect female labor force participation in Bangladesh. This study uses two sorts of quantitative methodologies. Methodology 1 examines the correlation between female labor force participation rate, female literacy rate, and female employment in three economic sectors in Bangladesh. Methodology 2 estimates an ordinary regression model where female labor force participation is the dependent variable and GDP per capita on PPP is the independent variable. The study uses the female unemployment rate, fertility rate, and urbanization as controlled variables with annual data spanning from (1991 -2019) by collecting data from secondary sources such as government institutions, World Bank, journals, and websites.

\section{METHODOLOGY}

Correlation between Female labor force participation rate and Female literacy rate (1981-2019)

Among the various macro-level factors that affect female labor force participation, education is one of them. In global literacy, Bangladesh recently ranks 128th, with an educated population aged 15 or older (72.8 percent), connected to the 86 percent average universal. The multiple original data shows 24 percent of people aged 15-24 in Bangladesh have not achieved primary education, and 44 percent have not performed secondary education. Figure 1 shows the adult literacy rate (Female) and Youth Literacy rate (15-24) for the period of 1981 to 2019. 


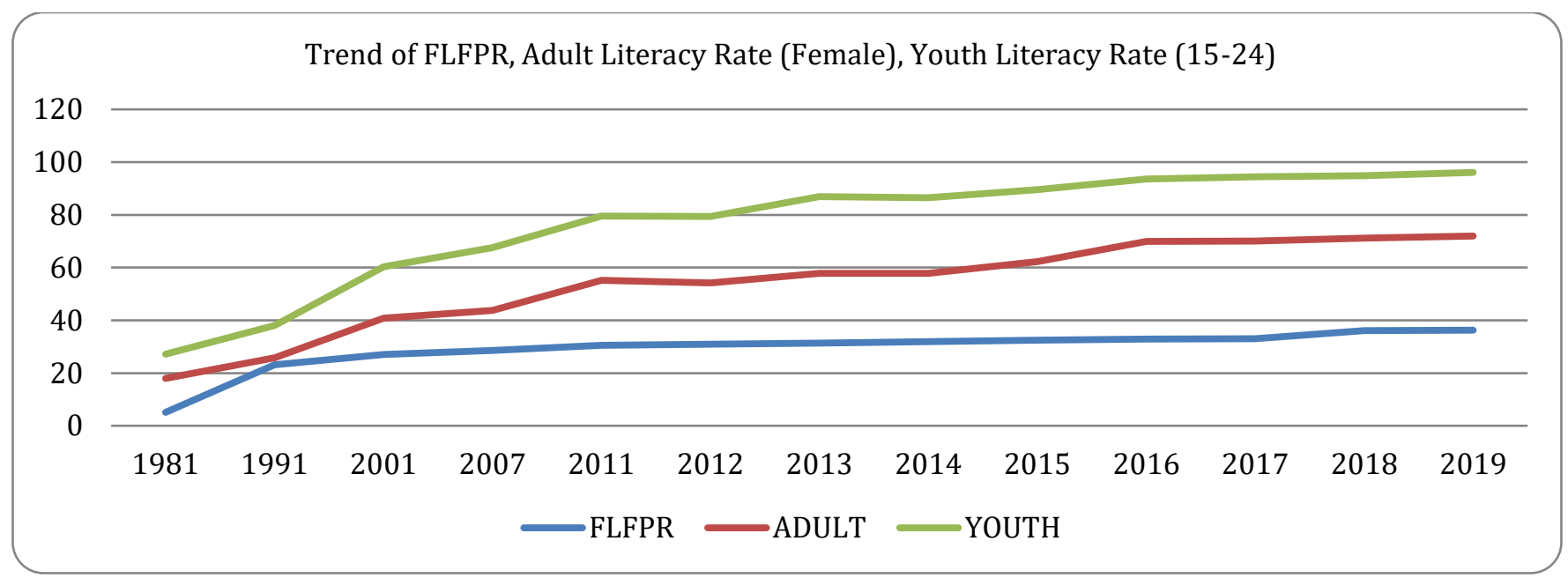

Figure 1. Female Labor Force Participation Rate and Female Literacy Rate (1981-2019).

Source: Author generated graph using the UNESCO data

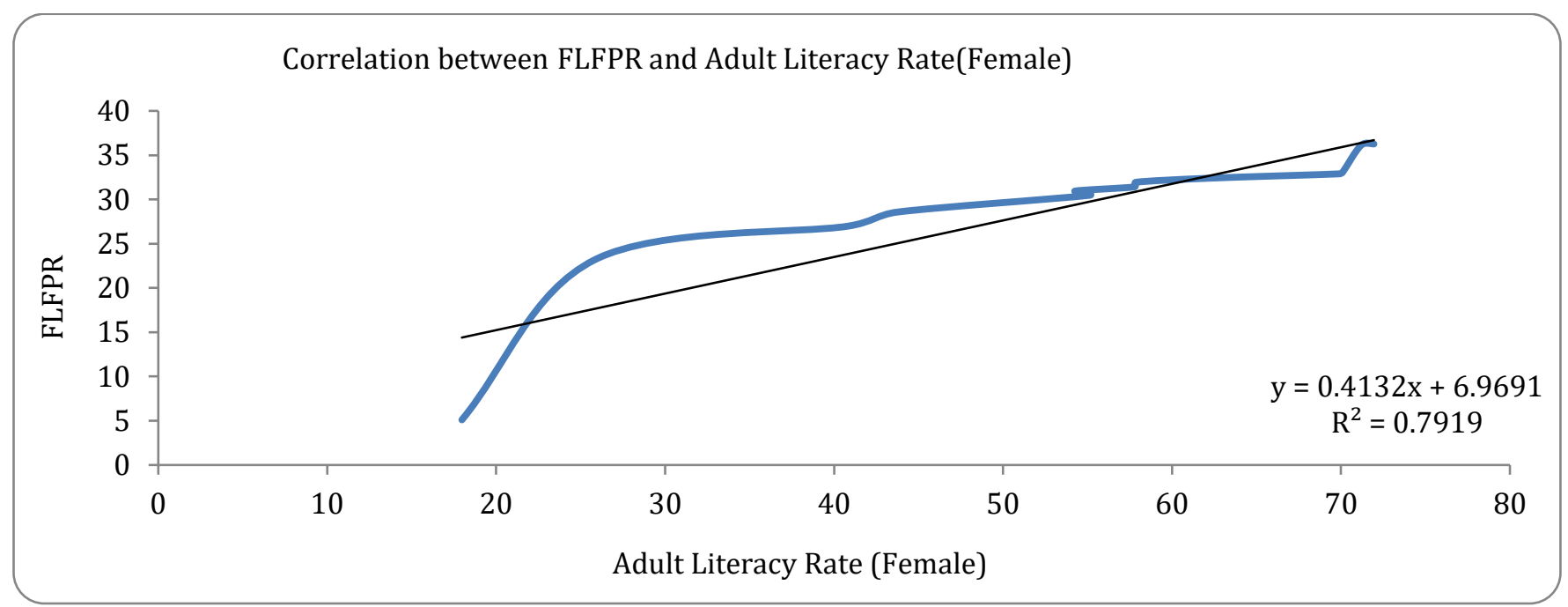

Figure 2. Scatterplot 1: Correlation between FLFPR and Adult Literacy rate (Female).

Source: Author generated graph using the UNESCO data

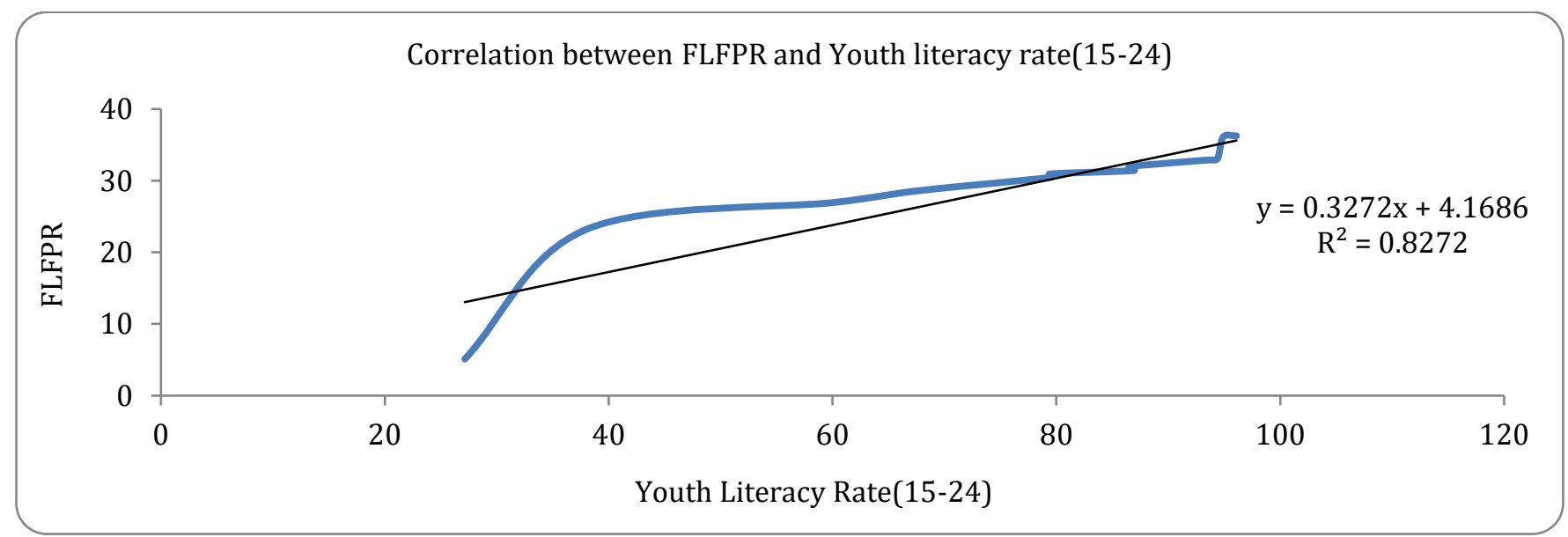

Figure 3. Scatterplot 2: Correlation between FLFPR and Female ages (15-24) literacy rate.

Source: Author generated graph 
Figure 2 shows the scatterplot of FLFPR and Adult literacy rate (Female). The graph shows that there is a positive relationship between the two indices. Indeed, the estimated regression equation shows that an increase in Adult Literacy Rate (Female) by one percentage point leads to a 0.41 percentage point increase in FLFPR and vice versa. The estimated correlation coefficient between the indices is 0.89 , which suggests that the two indices are highly positively correlated. As shown in Figure 3, the scatter plot of Youth Literacy Rate (15-24) and FLFPR shows that the two indices are highly positively correlated. The correlation coefficient is 0.91 . The regression coefficient suggests that a one percentage point increase in Youth literacy rate (15-24) leads to a 0.33 percentage point increase in FLFPR and vice versa.

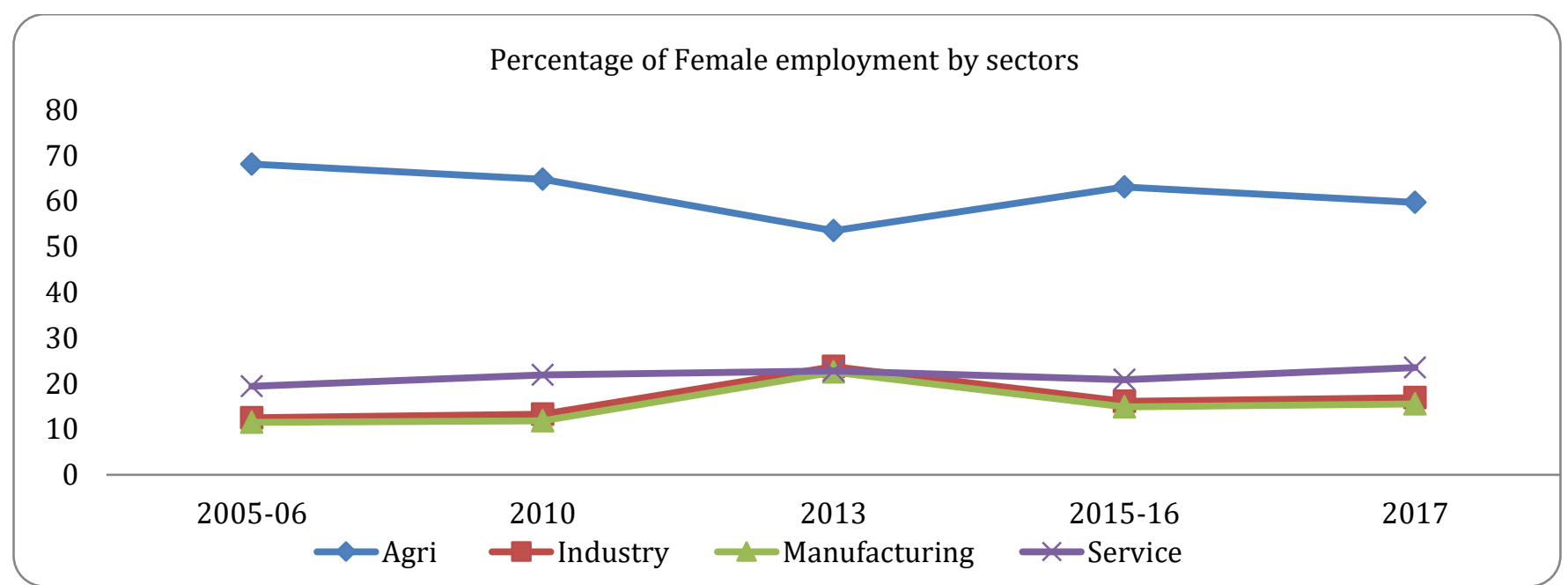

Figure 4. Percentage of Female Employment by sector.

Source: Author generated graph using various LFS Data

As shown in Figure 4, we can see that Female labor force participation in Industry and Service sector has increased, whereas participation in Agriculture has decreased. The female workforce is very familiar with agricultural work. But the more they will educate, the more their participation will increase in the service sector also the industry sector. So, the female labor force participation rate is improving even before but not up to the mark.

\section{Model Specification}

\section{Model 1}

$F L F P R t=\alpha 1+\beta 1 \operatorname{Ln}(G D P p c P P P) t+\beta 2(\operatorname{Ln} G D P p c P P P) 2 t+$ $U t---(1)$

Where:

FLFPRt $=\quad$ Female Labor Force Participation Rate Ln GDPpcPPPt $=$ Natural Log of GDP per capita PPP
(Ln GDPpcPPP)2t = Square of Natural Log of GDP per capita PPP

Ut $=$ Error Term

$\mathrm{t}=$ indicate time

The model is a Lin-Log model. Here the Regressor is the natural log of GDP per capita on PPP in constant 2011 US dollar. A high volume of literature accepts per capita, real GDP as a proxy of economic growth. But the study uses GDP per capita on PPP as a proxy of economic growth. Sinha (1967) noted that the U shape reflects the initial stage of declining female labor force participation rate with economic growth so $\beta 1<0$. At the later stage of economic development, women get access to education. Women's opportunities in getting white-collar jobs are available for the expansion of the service sector also the industry sector. So, the expected sign of coefficient $\beta 2>0$.

Table 2. Regression Results.

\begin{tabular}{|c|c|c|c|c|}
\hline Variables & Coefficient & Std.Error & $\mathrm{t}$ & $\mathrm{p}>\|\mathrm{t}\|$ \\
\hline CONSTANT & 18.13964 & 25.32494 & 0.72 & 0.480 \\
\hline LNGDPPCPPP & -3.961096 & 6.627526 & -0.60 & 0.555 \\
\hline (LNGDPPCPPP) 2 & 0.6960921 & 0.4319065 & 1.61 & 0.119 \\
\hline
\end{tabular}

Source: Author's calculation based on STATA. 
Table 3. ANOVA.

\begin{tabular}{|c|c|c|c|}
\hline Source & SS & $\mathrm{df}$ & MS \\
\hline Model & 363.522512 & 2 & 181.761256 \\
\hline Residual & 8.12036593 & 26 & 0.312321767 \\
\hline \multirow[t]{4}{*}{ Total } & 371.642878 & 28 & 13.2729599 \\
\hline & \multicolumn{2}{|c|}{ R-Square= } & 0.9782 \\
\hline & \multicolumn{3}{|c|}{ Adjusted R-Square= } \\
\hline & \multicolumn{3}{|c|}{$F(2,26)=581.97$} \\
\hline
\end{tabular}

Source: Author's calculation based on STATA

The estimation result (Table2) shows that the coefficient of log of GDP per capita PPP is negative, which means $\beta 1<0$, but the t-value is highly insignificant. The coefficient of the square of log of GDP per capita PPP is positive as predicted $\beta 2>0$, and its t-value is barely statistically significant. $\mathrm{F}$ ratio is high, which means that the model is valid (as shown in Table 3). So, a U-shape exists in Bangladesh, but in practice, Bangladesh does not fit for U-shape, shown in Figure 5, with taking the Female labor force participation in Bangladesh for the period (1991-2019). And in Figure 6, we have shown the relationship between GDP per capita PPP and Female labor force participation rate (FLFPR). Figure 6 shows that there is a relationship between economic growth and female labor force participation rate. We got an upward shape female labor force participation rate, not a U-shape for Bangladesh perspective.

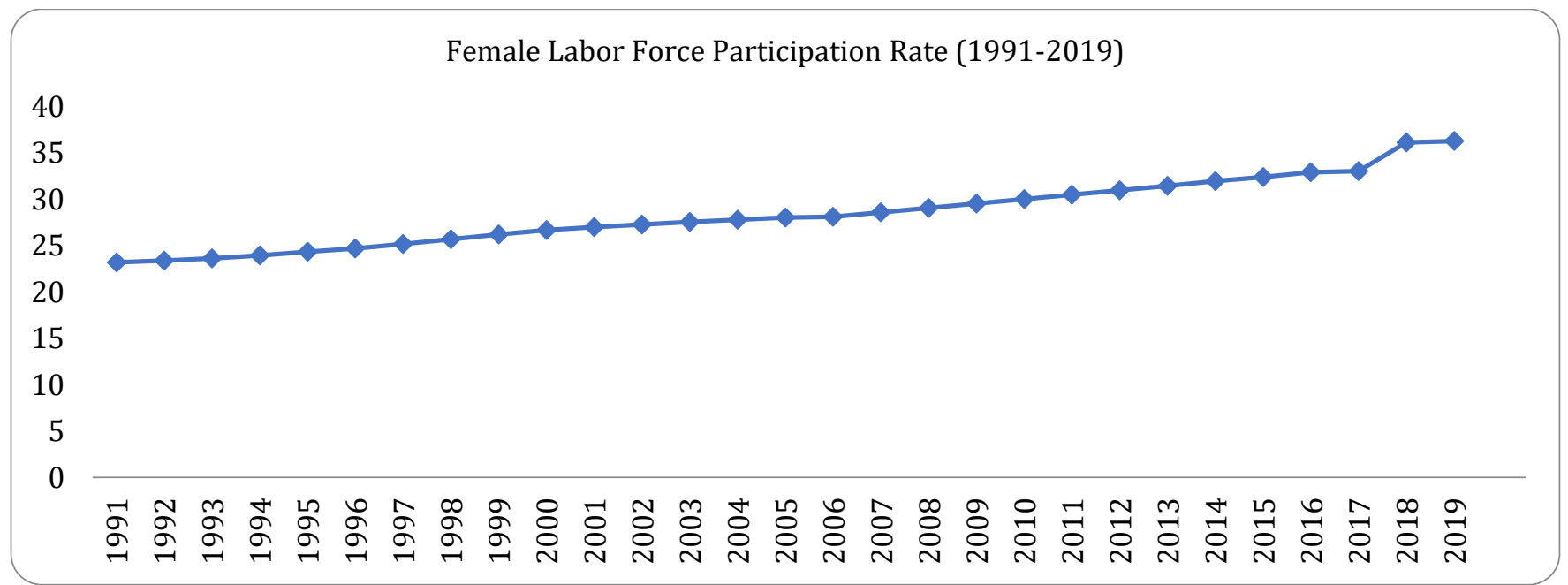

Figure 5. Female Labor Force Participation Rate (1991-2019).

Source: Author generated graph using various LFS Data.

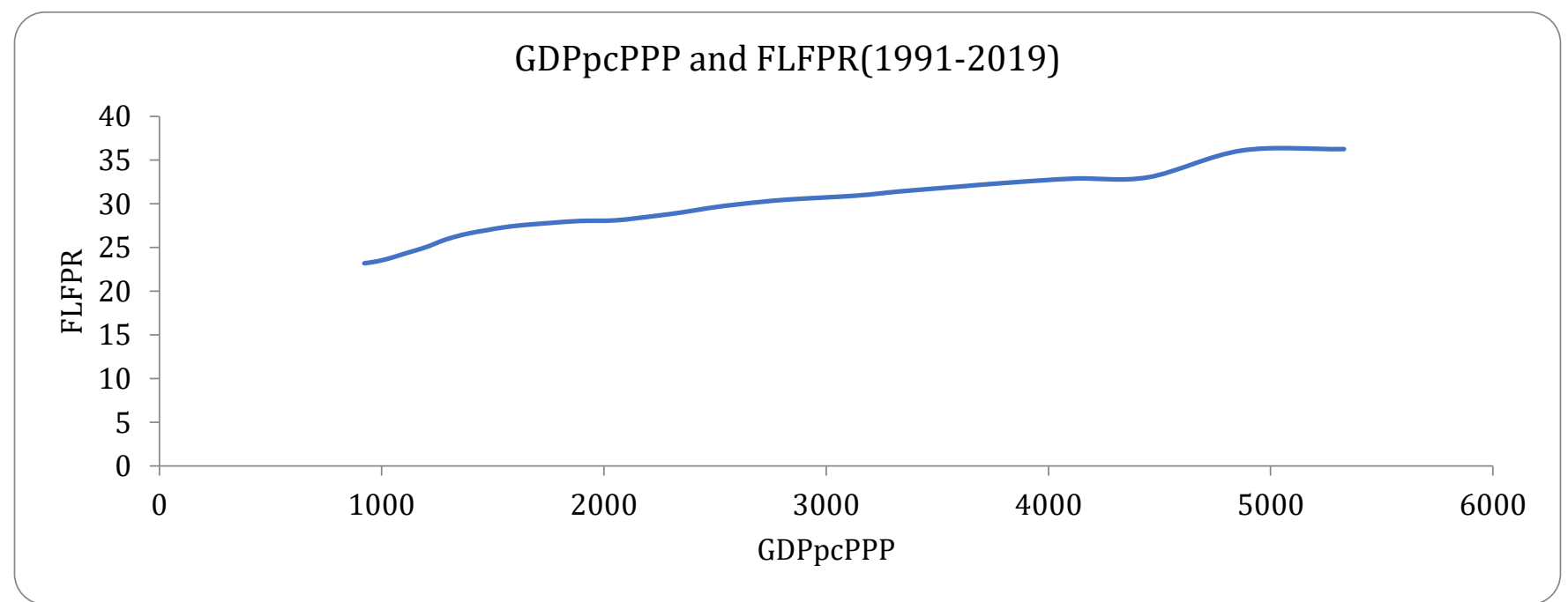

Figure 6. Relationship between GDPpcPPP and FLFPR (1991-2019).

Source: Author generated scatter diagram using LFS Data for FLFPR and World Data Atlas Data for GDPpcPPP. 


\section{Model 2}

FLFPRt $=\alpha 1+\beta 1 L n(G D P p c P P P) t+\beta 2 L n(G D P p c P P P) 2 t+$ $\beta 3 L n F R t+B 4 L n F U R t+\beta 5 L n U R B t+U t$

Where:

Ln FRt $=$ Natural Log of Fertility Rate

Ln FURt $=$ Natural Log of Female Unemployment Rate

Ln URBt $=$ Natural Log of Urbanization

Ut $=$ Error Term $\mathrm{t}=$ indicate time

Model 2 includes controls for female population rate, fertility rate, mortality rate, and urbanization. For the Ushape to hold, I would expect $\beta 1<0$ and $\beta 2>0$. I would expect the

coefficients of the female unemployment rate; fertility rate to be negative; the coefficient of urbanization to be positive.

Table 4. Regression Results.

\begin{tabular}{lllll}
\hline Variables & Coefficient & Robust Std.Error & $\mathrm{t}$ & $\mathrm{p}>|\mathrm{t}|$ \\
\hline Constant & 204.6666 & 123.5718 & 1.66 & 0.111 \\
LnGDPpcPPP & -25.72907 & 30.10043 & -0.85 & 0.401 \\
(LnGDPpcPPP)2 & 2.615103 & 1.663008 & 1.57 & 0.129 \\
Ln FR & -11.68346 & 6.926847 & -1.69 & 0.105 \\
Ln FUR & 1.683546 & 0.9200059 & 1.83 & 0.080 \\
Ln URB & -37.18528 & 12.5771 & -2.96 & 0.007 \\
& & R-Square & $=$ & 0.9880 \\
& Adjusted R-Square $=$ & 0.9854 & \\
& F $(5,23)$ & $=$ & 380.33 & \\
\hline
\end{tabular}

Source: Author's calculation based on STATA

The regression result (Table 4) shows that the Fertility rate and Urbanization have a negative sign on female labor force participation rate. But Female unemployment rate has a positive impact on the female labor force participation rate. $\mathrm{F}$ ratio is very high, which means that the model is valid. The value of $\mathrm{R}$ square and Adjusted $\mathrm{R}$ square shows that the overall model is good, and we can say that the model explains 99 percent variation, and errors or residuals explain 1 percent. Log of GDP per capita PPP has an insignificant impact on female labor force participation, but its quadratic value is barely significant at a 10 percent p-value. The results suggest that growth by itself is not sufficient to increase women's economic activity, but the dynamics of growth matter. The coefficient on the log of per capita GDP is negative, and its squared value is positive and significant. The quadratic form of economic growth has a positive impact on the female labor force participation rate. But this is not sufficient for its sustaining upward trend. The literacy rate of females related to female labor force participation cannot include the unavailability of

data for the same period. The results do not support the U-shaped relationship between economic development and women's economic activity. So, we can summarize that the U-shape hypothesis does not work in the perspective of Bangladesh. Female labor force participation rises with the increase in the unemployment rate. Annexed worker impact is higher than pessimistic worker effect.

But the coefficient of the unemployment rate is positive that is exceeding expectations. The influence of the coefficient on fertility rates on female labor force participation is negative but is statistically significant in line with theory from the literature. Urbanization has a negative sign on the Female workforce. But our expectation of the coefficient of urbanization was positive. Now, if we include the value-added of the principal three sectors of GDP composition, agriculture, industry, and service sector be our explanatory variables, then the regression equation would be as follows:

\section{Model 3}

$F L F P R t=\alpha 1+\beta 1 \operatorname{Ln}(G D P p c P P P) t+\beta 2($ Ln GDPpcPPP $) 2 t$ $+\beta 3$ Agrivalt $+\beta 4$ Indusvalt $+\beta 5$ Servalt $+U t---------(3)$

Where:

Agrival $=$ Agriculture sector value added ( $\%$ of GDP) Indusval $=$ Industry sector value added ( $\%$ of GDP) Serval $=$ Service sector value $\operatorname{added}(\%$ of GDP)

In Model 3, I expect $\beta 3<0, \beta 4>0$, and $\beta 5>0$. Expanding the industry sector creates more opportunities for females as 
a workforce, the coefficient $\beta 4$ to be positive.

The sign of coefficient $\beta 3$ will be negative because the agriculture sector will decline in the value-added over time. The expected sign of coefficient $\beta 5$ will be positive if the service sector starts to expand and encourage women to come out from the social stigma and give honorable women a friendly job platform.

Table 5. Regression Results.

\begin{tabular}{|c|c|c|c|c|}
\hline Variable & Coefficient & Robust Std. Error & $\mathrm{t}$ & $\mathrm{P}>|\mathrm{t}|$ \\
\hline Constant & 135.7129 & 60.14092 & 2.26 & 0.034 \\
\hline Ln GDPpсPPP & -25.35585 & 18.68653 & -1.85 & 0.077 \\
\hline (Ln GDPpcPPP)2 & 2.011967 & 0.8589217 & 2.34 & 0.028 \\
\hline Agrival & -0.4250403 & 0.2888965 & -1.47 & 0.155 \\
\hline Indusval & -0.3635359 & 0.3343604 & -1.09 & 0.288 \\
\hline \multirow[t]{4}{*}{ Serval } & -0.2747894 & 0.3879374 & -0.71 & 0.486 \\
\hline & R-Squared & 0.9839 & & \\
\hline & $F(5,23)$ & 613.38 & & \\
\hline & Observations & 29 & & \\
\hline
\end{tabular}

Source: Author's estimation based on STATA

As shown in Table 5, the agriculture sector, industry sector and service sector are statistically insignificant. These three sectors do not have an impact on the female labor force participation rate. But the results are not expected. Log of GDP per capita PPP and its quadratic value both are statistically significant. This significance is the indication of a U-shape relationship for Bangladesh. But through structural change, women are getting engaged in the service sector also industry sector by education. The performance of women in the agriculture sector is deteriorating, which is the base of the Uhypothesis. But in Bangladesh, female workforces are still working in the agricultural occupation. The movement of female labor forces from the agriculture sector to industry and service level is not up to the mark which it should be. The participation of female labor forces in the industry sector is declining nowadays for a high technological revolution. R-Squared value is 0.9839 , which means that the mode; explains 98 percent of variables, and the high F-statistics suggest that the model is valid. Finally, we can say that U-hypothesis cannot be applicable in Bangladesh.

\section{CONCLUSION}

The paper has verified the U-shaped hypothesis in Bangladesh by three models. The study concludes that Model 1 fulfilled the characteristics of the U-shape hypothesis for Bangladesh. But in practice, the U-shape cannot fit Bangladesh. Because the female labor force participation rate is a complex variable that is affected by so many micro and macro-level factors. The changing nature of female labor force participation has been a critical dimension of the development process since the Industrial Revolution increases participation of women in the labor market have played a pivotal role in driving the demographic dividend and pushing economic growth. Model 2 regression result shows that the unemployment rate of female has a positive significant impact while Fertility rate and Urbanization have a negative significant impact on female participation rate in the labor force. But the quadratic term of GDP per capita PPP has a significant impact on the female labor force participation rate. The study also investigated the correlation between female labor force participation rate and female literacy rate, where youth literacy rate (15-24) is ahead of the adult literacy rate of females. This study describes the graphical presentation of the status of female employment in three economic sectors. The female labor force is participating in the service sector also industrial sectors, and their performance is deteriorating in the agricultural, not at a satisfactory level. Model 3 describes the empirical discussion of the three sectors related to GDP. Policymaker should take steps to improve the education level of females that will contribute to an increasing female participation rate of female in the labor force.

This paper also estimates the threshold level of GDP per capita PPP beyond which the female labor participation expedites growth for Bangladesh economy by which we decided that U-shape does not exist in Bangladesh. There is just an upward shape for the female labor force 
participation rates have in Bangladesh. Future studies should focus on a more concrete analysis of the factors, particularly education, marital status, religious values, social norm and cultural attitudes, childcare policies. A female-friendly environment plays a pivotal role in determining the female labor force participation rate in Bangladesh. Without having the proper control variables, it may not be possible to estimate the relationship between economic development and female labor force participation rate.

\section{CONTRIBUTION OF THE STUDY}

The study has introduced an efficient framework of the trade-off between economic development and female labor force participation in Bangladesh by the OLS method. As far as I know, for the first time, the research study has examined the U-shaped of all South Asian countries.

\section{REFERENCES}

Altarawneh, Yaseen, M. (2020). Economic Development and Female Labor Force Participation in Jordan: A Test of the U-Shaped Hypothesis. Jordan Journal of Economic Sciences, 7(1), 109-120. www.researchgate.net

Altuzarra, A., Galvez-Galvez, C. \& Gonzalez-Flores, A. (1962). Economic Development and Female Labor Force Participation: The Case of European Union Countries. Sustainability, 11(7), 1-18. https://doi.org/10.3390/su11071962

Boserup, E. (1970). Women's Role in Economic Development, New York: St. Martin's Press.

Chapman, K. A., (2015). Economic development and female labor force participation in the Middle East and North Africa: A test of the U-shape Hypothesis. Gettysburg Economic Review, 8(3): 3-20. https://cupola.gettysburg.edu/ger/vol8/iss1/3

Chaudhary, R. \& S. V. (2014). Female labor force participation in India and beyond. ILO Asia Pacific Working Paper Series, ISSN 2227 - 4391 International Labor Organization. https://www.ilo.org/wcmsp5/groups/public/@a sia/@ro-bangkok/@sro-

new_delhi/documents/publication/wcms_324621 .pdf

Durand, J. D. (1975). The labor force in economic development: A comparison of international census data 1946-66. Princeton, NJ: Princeton University
Press.

Gaddis, I. \& S. K. (2013). Economic development, structural change, and women's labor force participation. J Population Economics, 27(3): 639681. DOI: $10.1007 / \mathrm{s} 00148-013-0488-2$.

Goldin, C. (1995). The U-Shaped Female Labor Force Function in Economic Development and Economic History, in T.P. Schultz (ed.). Investment in Women's Human Capital, Chicago: The University of Chicago Press.

Gunatilaka, R. (2013). Women's Participation in Sri Lanka's Labour Force: Trends, Drivers and Constraints.Colombo, Sri Lanka: ILO, 2013.

Husain, H. (2016). Economic Development, Women Empowerment and U-Shaped Labor Force Function: Time series Evidence for Bangladesh. Asia Economic and Financial Review, 2016, 6(12):719-728

Khaliq, A., Khan D., Akbar, S., Hamayun, M. \& Ullah B. (2017). Female Labor Market Participation and Economic Growth: The Case of Pakistan, Journal of Social Science Studies, 4(2), 1-25.

Lahoti, R., \& Swaminathan, H. (2016). Economic Growth and Female Labor Force Participation in India. Feminists Economics, 22(2), 1-47. . https://doi.org/10.1080/13545701.2015.106602 2

Mahmud, S. (2003). Is Bangladesh Experiencing Feminization of the Labor Force? Bangladesh Development Studies. 29(1): 1-37. DOI: $10.2307 / 40795670$

Mahmud, S., \& Bidisha, S. H. (2018). Female Labor Market Participation in Bangladesh: Structural Changes and Determinants of Labor Supply. (pp. 51-63), In Structural Change and Dynamics of Labor Markets in Bangladesh. Singapore: Spinger.

Mehrotra, S. \& Prida, J. k. (2017). Why is the Labor Force Participation of Women declining in India? World Development, Elsevier, 98(C), 360-380, DOI: 10.1016/j. world dev.2017.05.00

Pampel, F.C. \& K. T. (1986). Economic development and female labor force participation: A reconsideration. Social Forces, 64(3), 599 -619.

Roy, S. (2018). An Endeavour to empirically verify the 'Feminization ' $U$ ' Hypothesis of Female Labor Force Participation Rate in India. Indian Journal of Economics and Development, 6(9), 1-11.

Sinha, J. N. (1967) "Dynamics of Female Participation in 
Economic Activity", Proceedings of the World Population Conference, Belgrade, 4, 336-337.

Tam, H. (2011). U - shaped female labor force participation with economic development. Economics Letters, 110(2), 140-142.

Tansel, A. (2001). Economic Development and Female Labor Force Participation in Turkey: Time-Series Evidence and Cross-Province Estimates, ERC Working Papers 01/05.

Verma, N.M.P. (1990). Female Labor and Work Participation: Validity of the Existing Hypothesis.
Manpower Journal, XXVI(1), 1-11.

Verick S. (2018, December). Female Labor Force Participation and Development. IZA World of Labor 2018, 87(2), 1-11. doi: 10.15185/izawol.87.v2, wol.iza.org

World Bank. (2020, March 8-13). South Asia Women in the Workforce Week, South Asia, https://thedocs.worldbank.org/en/doc/3481215 833428891130080022020/render/WomenWorkf orceWeekBrief.pdf

\section{APPENDIX}

Figure numbers 1 to 8: Relation between GDPpcPPP and FLFPR of South Asian Countries

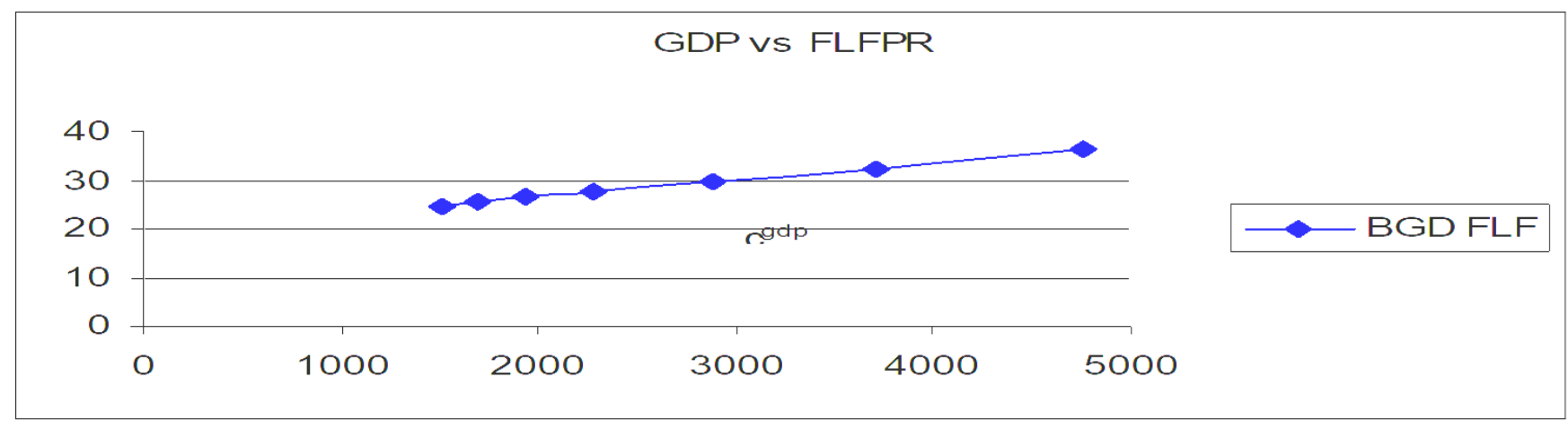

Figure 1. *BGDFLF=Bangladesh Female Labor Force Participation Rate

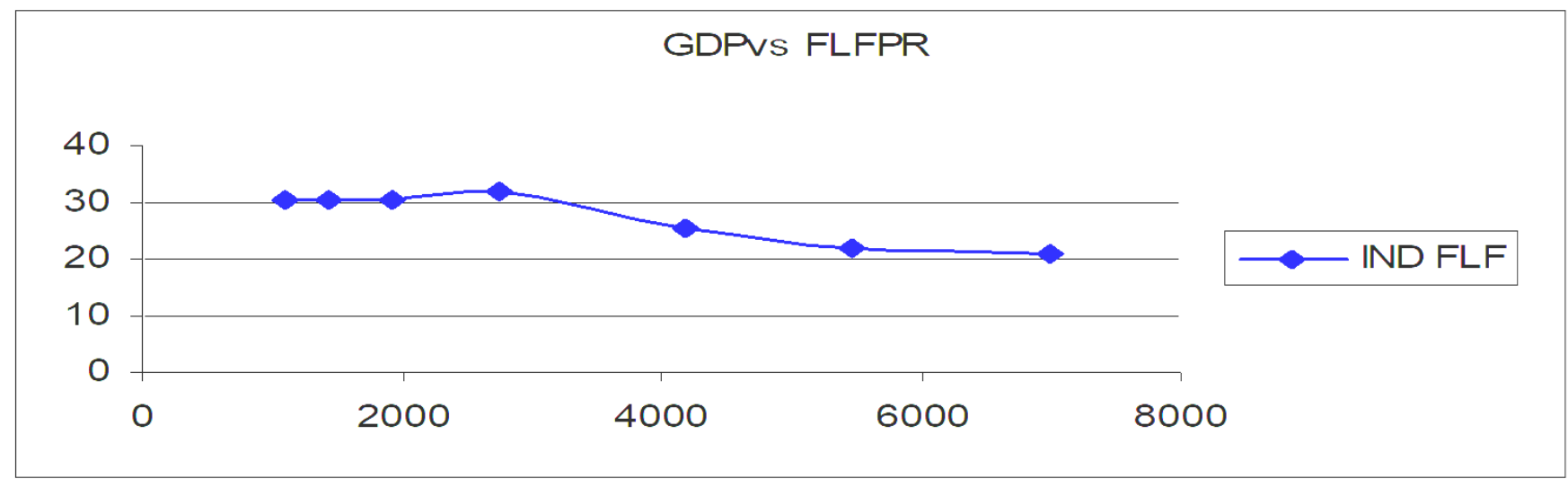

Figure 2. *INDFLF=India Female Labor Force Participation Rate 


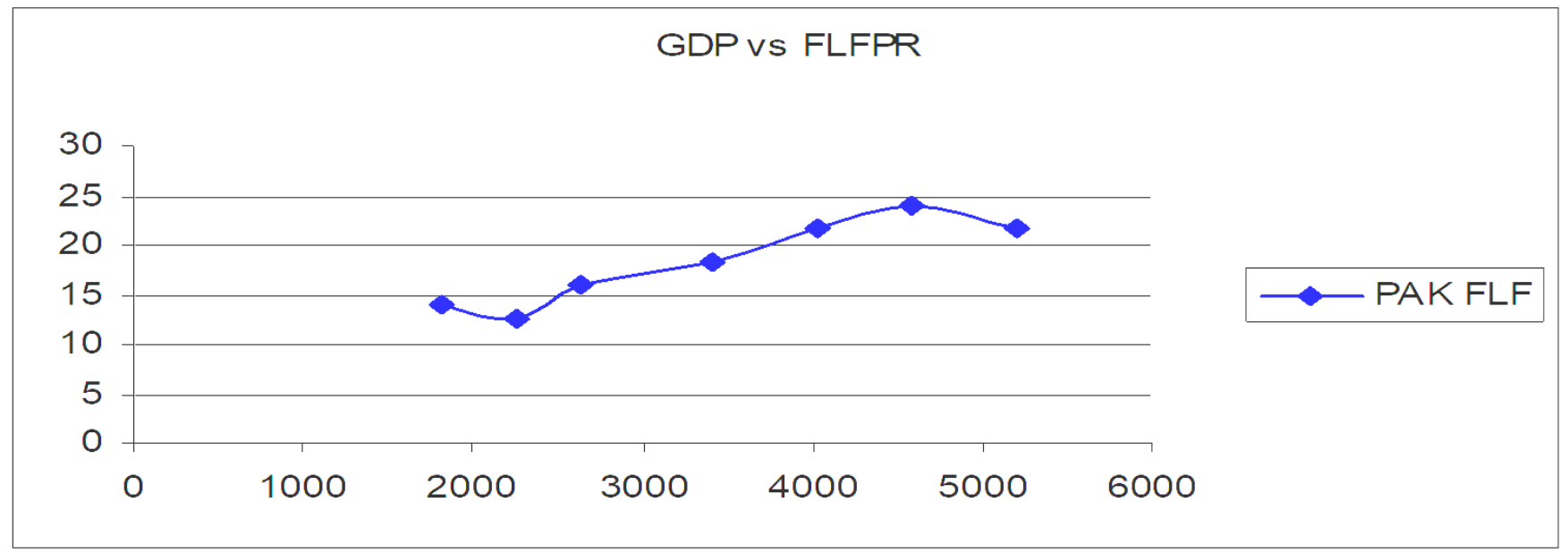

Figure 3. *PAKFLF=Pakistan Female Labor Force Participation Rate

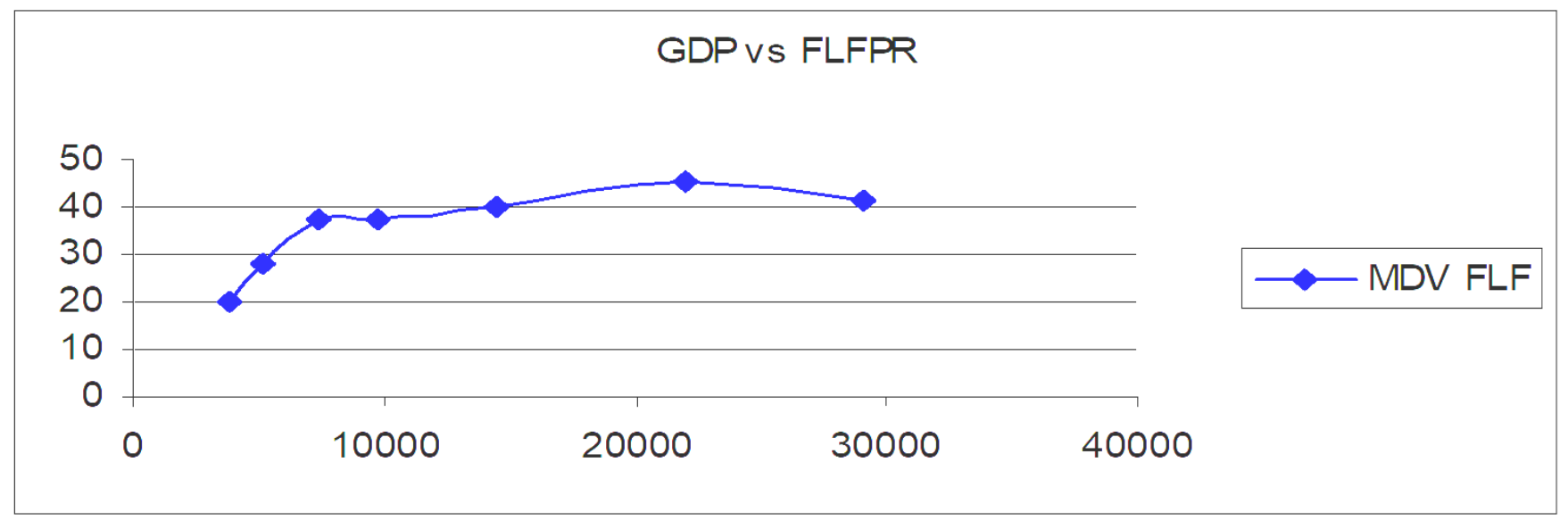

Figure 4. *MDVFLF=Maldives Female Labor Force Participation Rate

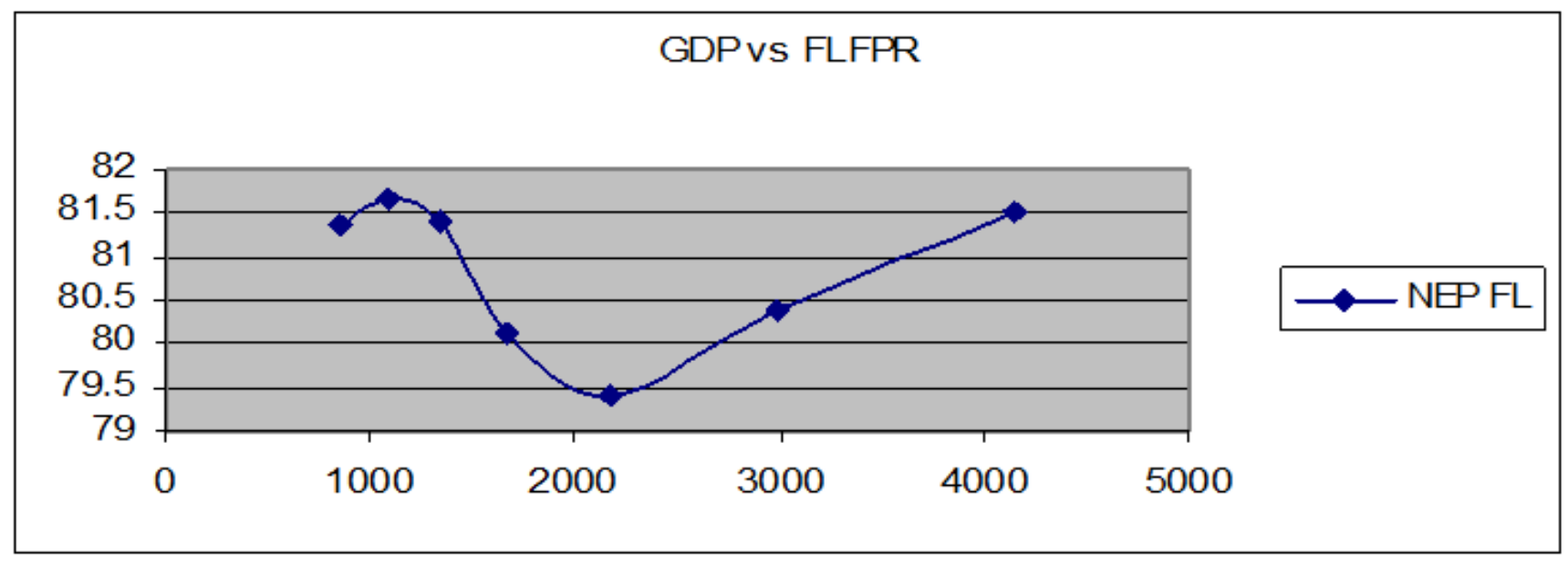

Figure 5: *NEPFL= Nepal Female Labor Force Participation Rate 


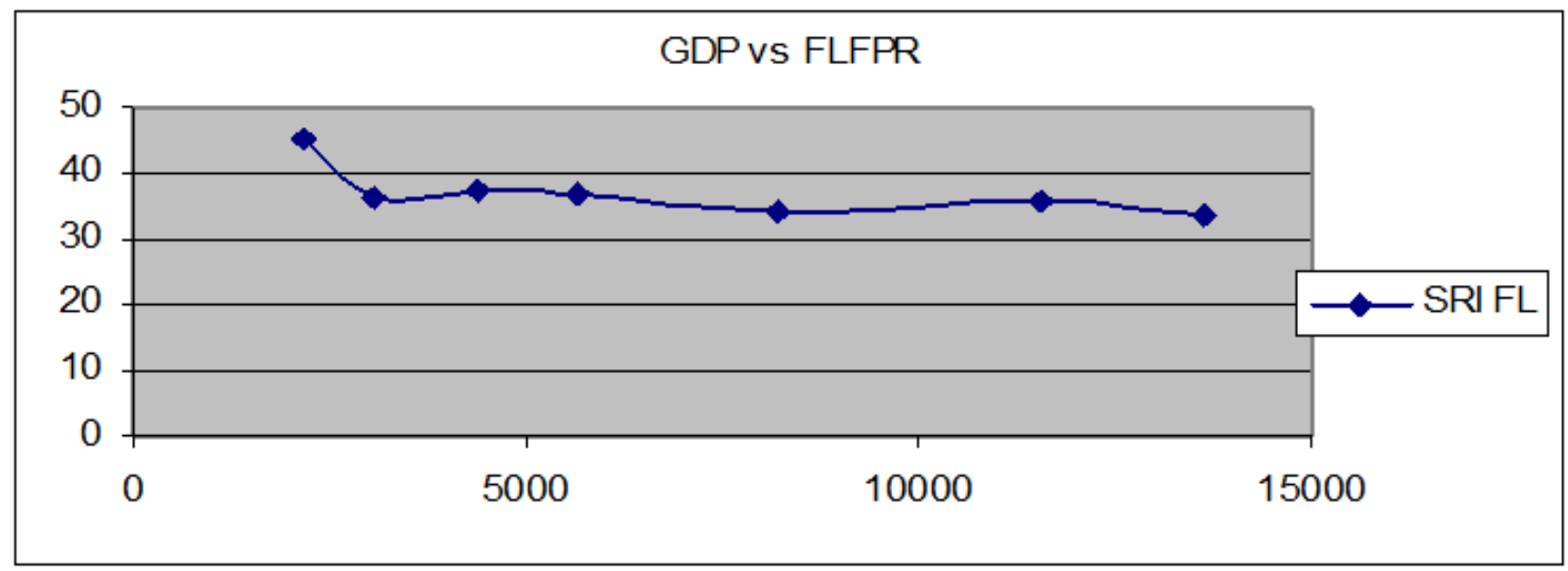

Figure 6: *SRIFL= Sri Lanka Female Labor Force Participation Rate

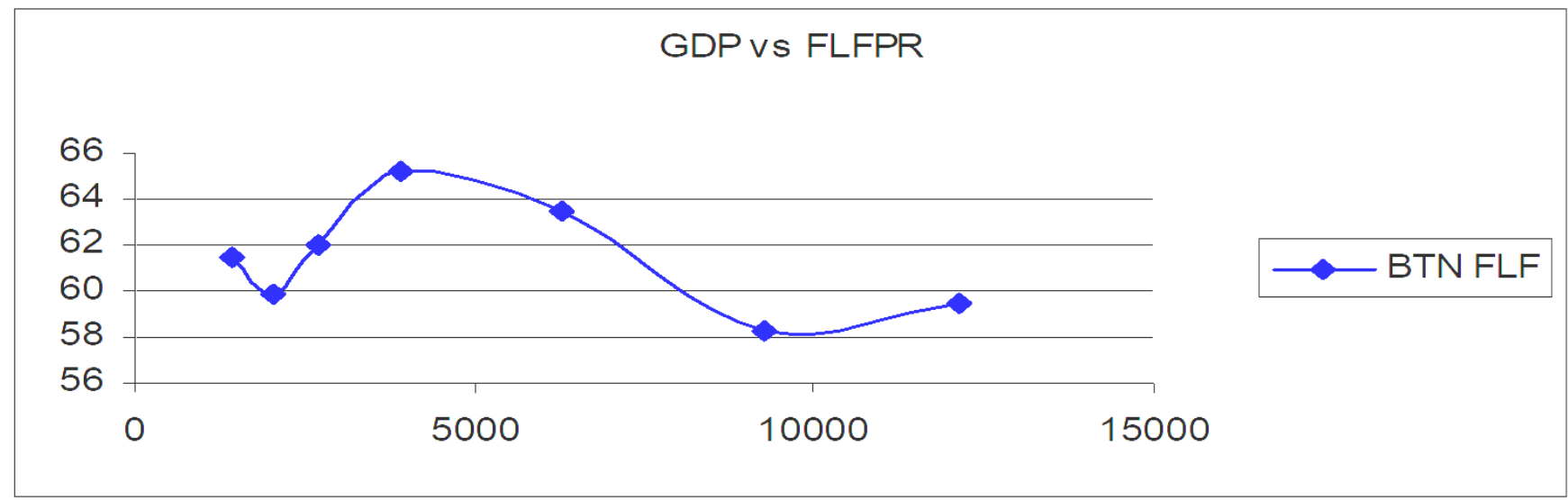

Figure 7. *BHUFLF=Bhutan Female Labor Force Participation Rate

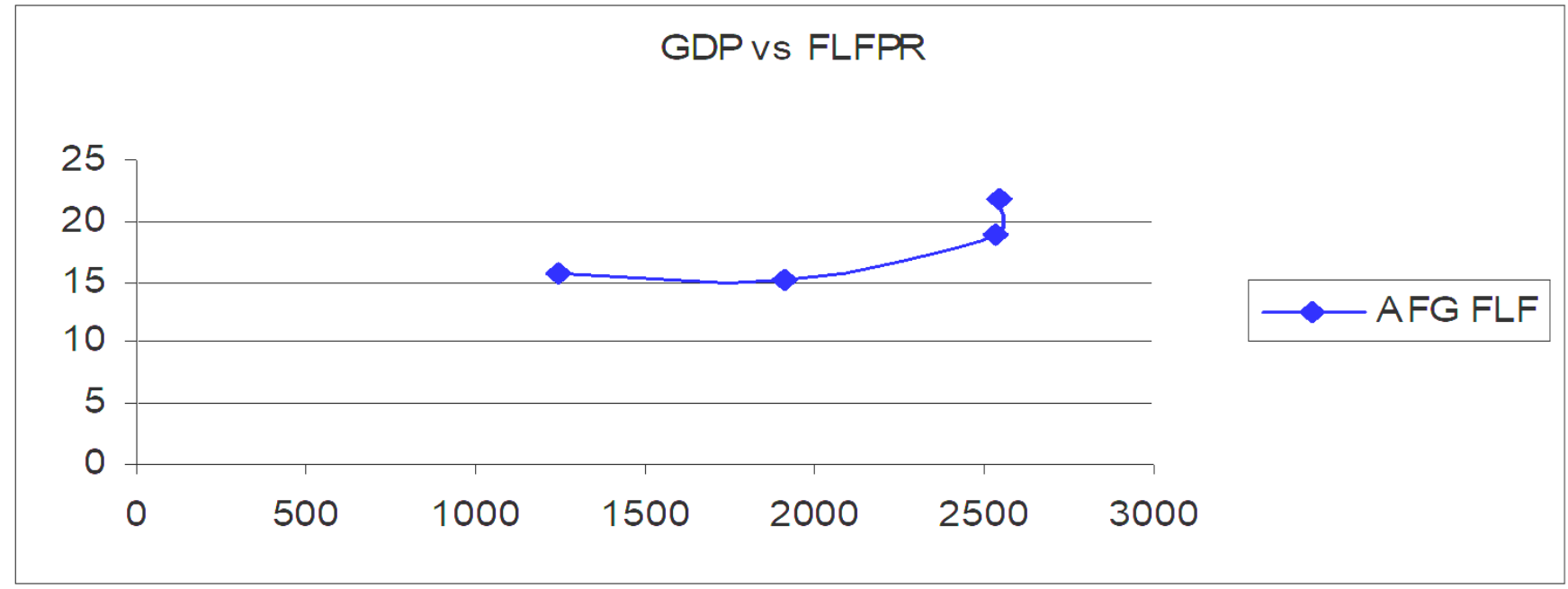

Figure 8. *AFGFLF=Afghanistan Female Labor Force Participation Rate

Source: Author generated graph using ILOSTAT Data for FLFPR and World Data Atlas Data for GDPpcPPP for all South Asian Countries 
Publisher's note: EScience Press remains neutral with regard to jurisdictional claims in published maps and institutional affiliations.

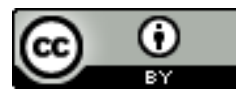

Open Access This article is licensed under a Creative Commons Attribution 4.0 International License, which permits use, sharing, adaptation, distribution and reproduction in any medium or format, as long as you give appropriate credit to the original author(s) and the source, provide a link to the Creative Commons license and indicate if changes were made. The images or other thirdparty material in this article are included in the article's Creative Commons license, unless indicated otherwise in a credit line to the material. If material is not included in the article's Creative Commons license and your intended use is not permitted by statutory regulation or exceeds the permitted use, you will need to obtain permission directly from the copyright holder. To view a copy of this license, visit http://creativecommons.org/licenses/by/4.0/.

(C) The Author(s) 2020 . 